ЕКОНОМІКА ЯК НАУКА. ТЕОРІЯ, ПОЛІТИКА І ПРАКТИКА

UDC 330.342: 303.725 .2

DOI: http://dx.doi.org/10.30970/ves.2020.59.0.5901

JEL P510, Q570

\title{
DEVELOPMENT OF METHODOLOGY FOR COMPARATIVE ANALYSIS OF ECONOMIC SYSTEMS UNDER STRENGTHENING OF THEIR ECOLOGIZATION
}

\author{
Bohdan. Kulchytskyj ${ }^{1}$, Yaroslav. Kulchytskyj ${ }^{2}$, Petro. Ostroverkh ${ }^{1}$, Tetyana. Moryak ${ }^{1}$ \\ ${ }^{1}$ Ivan Franko National University of Lviv, \\ Svobody Ave., 18. UA-79008 Lviv, Ukraine; \\ E-mail: kulchytskyj.br@ukr.net \\ ${ }^{2}$ National University of Forestry and Wood Technology of Ukraine \\ Gen. Chuprynky str., 103. UA-79057 Lviv, Ukraine
}

\begin{abstract}
Annotation. Institutional principles of ecologization of the modern economic systems are exposed from positions of post-industrial paradigm and comparisons of economic systems in the conditions of strengthening of globalization. Maintenance of ecological paradigm of economic theory is educed and the necessity of selection of social-and-ecological relations is reasonable for the system of economic relations of society. Conception is analysed of steady development and feature of ecological-economic instruments in the developed countries.

Importance of forming of modern ecological culture is underline in the process of transformation of the economic systems, when in her basis must be oriented to ecological expediency and safety, absence of contrasting of man and nature. Authorial interpretation of process of ecologization of the modern economic systems is offered in the conditions of strengthening of globalization, transition of humanity to society of knowledge and "green economy". Under the ecologization of the economic systems we suggest to understand strengthening of ecological orientation of the economic systems in the process of their transformation, which appears in becoming of modern economic and ecological consciousness and culture, ecological responsebility, claim of modern ecological values, forming of corresponding normatively-legal, institutional base, sent to the public inspection after the system of connections a "man is an economy - ecology", application of approvals and stimuli in relation to influence of the economic system on the state of ecological equilibrium in the conditions of the limited nature of natural resources and intensifying of ecological crisis of global, regional and local character. An ecologization of the economic systems is the objective process of their transformation, by the dominant of transformation on the fracture of millenniums, which asserts realization of ecological problems as global. The
\end{abstract}

(C) B. Kulchytskyj, Ya. Kulchytskyj, P. Ostroverkh, T. Moryak, 2020 
ecologization of the economic systems is examined today as very important, even qualificatory criterion of comparative analysis of the national systems or international system educations. The ecological paradigm of the comparative analysis of the economic systems of XXI of century is reasonable.

Key words: economic systems, ecologization of the economic systems, environment development, ecological paradigm of economic theory and comparative analysis of the economic systems of XXI of century.

Introduction. In modern conditions of planetary existence of society, a comprehensive study of the content, structure, patterns of formation and development, features of economic systems and their comparative analysis are of particular importance. After all, as noted by the famous Ukrainian philosopher V. Melnyk, the world lives in anxious anticipation associated with the manifestation of numerous crises in virtually all spheres of civilization economic, environmental, political, cultural and others. The conquest of new heights of civilization causes at the same time unpredictable, unexpected dangers of a global nature, which threatens the reality of human existence $[15$, p. 3]. Thus, it is a fundamental philosophical paradigmatic discourse in modern economic theory and the theory of comparative economic systems or economic comparative studies. Substantiation of theoretical and methodological principles of comparative analysis of modern economic systems involves the identification of pronounced priority dominants of their transformation, which in the XXI century, in our opinion, are ecologization (greening) and globalization. It is these processes that are currently exerting a decisive influence on the functioning and transformation of existing or the formation of new economic systems. Being closely interconnected, they determine the key parameters of economic systems, determine their functions. And although the urgency of the problem of greening the economy is beyond doubt, but most of the existing research has either a purely economic, pragmatic bias, or environmental orientation in its purest form. Hence the need for a comprehensive approach to this problem based on the dialogue of economics and other sciences. In addition, the study of ecologization of modern economic systems in the context of economic comparative studies is important for the methodology of economic theory, as well as policies to regulate the interaction of economic and ecological systems and ensure sustainable development of economic systems in the context of globalization.

In our opinion, the ecologization of modern economic systems is a characteristic feature of the formation of information, "knowledge", post-industrial society. Accordingly, the comparative analysis of economic systems through the prism of strengthening their greening, taking into account the epoch-making transition from economic man (homo economicus) to creative man (homo creator), must be based on the post-industrial paradigm, which, in our opinion, will ensure the objectivity of such comparative analysis.

The study of the theoretical and methodological foundations of modern economic systems objectively involves identifying the priority dominants of their transformation, which in the XXI century are, in our opinion, greening and globalization. It is these processes that are currently exerting a decisive influence on the functioning and transformation of existing or the formation of new economic systems. Being closely interconnected, they determine the key parameters of economic systems, their elemental structure, determine the most important functions. And although the urgency of the problem of greening the economy is beyond doubt, but most of the available research has either an exclusively economic, pragmatic bias, or environmental orientation in its purest form. Hence the need for a 
comprehensive approach to this complex and important theoretical and practical problem based on the dialogue of economics and other sciences.

The aim of our article is to develop theoretical and methodological principles of research and elucidation the meaning of modern economic systems greening in the context of comparative systems theory or economic comparative studies of the XXI century, which is very important for the methodology of economic theory and practice of state regulation of economic and ecological systems. and ensuring the sustainable development of both developed and transitional economic systems in the face of increasing globalization.

We prove the need for a theoretical separation of socio-ecological relations in the system of economic relations of society and reflection this in the conceptual apparatus of economic theory. We reveal the content and consider it appropriate to introduce into scientific circulation in economic theory the concept of "ecologization of economic systems". In addition, we offer a number of environmental indicators-criteria for comparative analysis of modern economic systems, which together constitute the content of the ecological paradigm of economic comparative studies of the XXI century.

The methods of our research are: dialectical, historical, logical, analysis and synthesis, systemic, synergetic, comparative analysis, scenario approach, interdisciplinary and others.

Degree of problem development and literature review. It should be emphasized that despite the significant urgency of the problem of paradigmatic changes in economic theory and economic comparative studies of the XXI century under the influence of increasing greening of economic systems as a priority of their transformation in the epoch-making transition of mankind to information, "knowledge" society and "green economy", the researchers often have quite different vision and interpretation of this problem. Therefore, we will try to identify the main approaches to its solution and justify our own scientific concept.

The study of economic and environmental activities at the beginning of the XXI century in the conditions of significant strengthening of objective processes of greening of modern economic systems presupposes, in our deep conviction, the need to revise many outdated methodological provisions of economic theory [1, P. 259; 10, PP. 68;11; 12;13; 14]. The practical reasons for such trends are acute problems of human and environment relations [ 1 , P. $259 ; 11 ; 12 ; 13 ; 14]$. As a result of these complex trends in economic theory and economic comparative studies, the ecological paradigm began to be firmly established, which requires the consideration of all economic and social processes through the prism of protection of environment, living conditions and development of human personality [1, P. 258-259; 2, PP. $240-241 ; 3 ; 4 ; 6 ; 9 ; 10$, PP. $68-69 ; 11 ; 12 ; 13 ; 14]$. As foreign researchers rightly point out in this context, the ecological paradigm of economic theory grows primarily from criticizing the possibilities of traditional neoclassical optimization analysis to solve the problem of degradation and environmental protection, as well as ensuring its quality and availability of natural resources for future generations [18, P. 22].

According to $\mathrm{Yu}$. Tunitsa, there are deep contradictions between the traditional market economy and environmental requirements. Therefore, the main problem of modern economics should be the formation of a new ecological economy: "Science must do everything possible to adapt the market model of the economy to the requirements of the ecological economy, moreover, in real life there must be a transformation of market economy into ecological" [17, P. 21]. The scientist rightly believes that economics at the beginning of the third millennium must change or at least significantly refine its paradigm, as the subject of classical and neoclassical economics becomes broader and more complex due to the 
expansion of the third factor of production "natural resources" to "natural environment" [17, PP. 26-27].

Modern foreign textbooks on economic theory do not take into account the environmental imperative, because it is necessary to study the behavior of people in the production, distribution and consumption of material goods and services not just in conditions of limited resources, but in new conditions - exacerbation of global, regional and local environmental crisis. According to $\mathrm{Yu}$. Tunitsa, it is a question of significant changes in the subject of economics or the formation along with the classical and neoclassical economic theory of a new ecologicaleconomic theory or ecological economy, which is, on the one hand, a product of economic thought in historical retrospect and based on the latest economic theory, and on the other - the result of observations and analysis of the modern world, its nature and society, the result of the analysis of completely new environmental problems [17, PP. 26-29]. In general, the scientist emphasizes: "On the one hand, ecological economics is an integral part of economic theory, on the other - it requires a radical change in the essence and content of economic sciences to reflect their environmental imperative ..." [17, P. 83].

We completely share the point of view of Yu. Tunitsa, who derives the ecological economy from economic theory and considers it a component of the latter. Indeed, no matter how lively is the dialogue of economics and other sciences, but updated and enriched with modern concepts and post-industrial paradigm, economic theory and economic comparativism is precisely the methodological foundation, the stream, in which ecological economics is distinguished as a reflection of the objective process of asserting of the ecological imperative in economic theory. Summing up the reflections on the ecological imperative in the modern economic theory, the scientist argues that "... it should be the ecologization of economics and other economic disciplines and, at the same time, the economization of ecology and other natural sciences" [17, P. 84].

Yu. Tunitsa convincingly substantiates and puts forward the idea of creating the Ecological Constitution of the Earth (ECE) and the need to develop and approve it as soon as possible [16, P. 203]. According to the researcher, the ECE should have the status of the Basic Law of Survival of Civilization and Sustainable Development, which, without threatening the sovereignty of any country, its political system, religion, national interests, would provide each state and whole world community the environmental and economic security, and for an individual - normal for his life natural conditions both now and in the future [17, pp. 195-196].

In developed economic systems, the ways to implement environmental and economic instruments are their respective forms, among which the most widespread are the following: 1) tax instruments; 2) customs duties; 3) payments; 4) fines; 5) subsidies; 6) grants; 7) grants; 8) credit instruments; 9) payments; 10) accelerated depreciation; 11) pricing instruments. Thus, in particular, in the industrialized countries of the world there is a growing trend of the role of environmental taxes and their stimulating effect on economic development. The share of environmental taxes in general taxation of legal entities and individuals is: in the US 3.2\%, Denmark - 3.4\%, Austria - 4.4\%, Canada - 4.5\%, Switzerland - 4.7\%, Germany - 4.9\%, France $-5.4 \%$, the Netherlands - 5.5\%, Greece - 6.1\%, New Zealand - 6.1\%, Japan - 6.5\%, Finland - 7.3\%, Spain - 7.5\%, Great Britain - 8.2\%, Italy - 9.0\%, Norway - 10.8\%, Portugal - $11.5 \%$, Ireland - $11.9 \%$ [16, P. 115].

The changes taking place today in developed economic systems must, in our deep conviction, be reflected in the theoretical separation of socio-ecological relations in the system of economic relations of society. At the same time, we believe that socio-ecological relations should be understood as relations that are objectively formed between the subjects 
of the economic system of society, ecological and economic activities in the process of conscious transformation of the natural world on the basis of appropriate economic and ecological culture. Such an approach would allow not only to focus the attention of theoretical scholars on the disclosure of the content and place of socio-ecological relations in the conceptual apparatus of economic theory and economic comparative studies, but also to give a powerful impetus to a comprehensive study of these relations in modern developed economic systems in order to take them into account in the economic and environmental policy of transition economies during their transformation in the context of increasing greening and globalization $[1$, p. 266; 2, pp.240-318; 3, pp. 105-121; 4; 5, pp. 54-58; 6; 11; $12 ; 13 ; 14]$.

Conclusions. Claiming the urgency of the public consciousness of the ecocentric system of values and guidelines, the idea of "green economy", we necessarily conclude a deep understanding of the importance of environmental consciousness and culture in the formation and transformation of economic systems, in improving the methodology of economic theory and economic comparative studies of XXI century. [1, pp. 275-280; 3; 4; 5, pp. 64-65; 6; 11; $12 ; 13 ; 14]$. The formation of modern ecological culture should be based primarily on the focus on environmental feasibility and safety, lack of opposition between a human and nature, the perception of natural objects as full partners in interaction with a human $[1, \mathrm{P}$. $278-279 ; 11 ; 12 ; 13 ; 14]$.

Further development of economic theory and economic comparative studies must take into account a certain isolation, autonomy of scientific research of environmental problems, on the one hand, and research of modern economic systems - on the other hand, as well as dialectical unity, continuity and deep interdependence, interdependence of environment, nature, ecosystems. and economic system. In this context, we consider it appropriate to introduce into scientific circulation in economic theory and economic comparative studies of the XXI century the concept of "greening of economic systems". Under the greening of economic systems, we propose to understand the strengthening of environmental orientation of economic systems in the process of their transformation, which is manifested in the formation of modern economic and environmental consciousness and culture, environmental responsibility, the establishment of modern environmental values, the formation of according to the system of relations "human - economy - ecology", the application of sanctions and incentives for the impact of the economic system on the state of ecological balance in conditions of limited natural resources and exacerbation of the ecological crisis of global, regional and local nature. The greening of economic systems is an objective process of their transformation, the dominant transformation at the turn of the millennium, which confirms the awareness of environmental problems as global. Greening of economic systems is considered today as a very important, even defining criterion for comparative analysis of national systems or supranational system entities.

We believe that the comparative analysis of modern economic systems in terms of increasing their greening, intellectualization and globalization should be based on the latest philosophical and methodological principles, which should include a civilizational, humanistic approach, based on the theory of information (post-industrial) society as a global methodological paradigm. type of economic and ecological consciousness and culture, polyphonic vision of economy, environment, spiritual, socio-political, legal and other spheres as a single social organism.

Accordingly, we propose a number of ecological indicators-criteria of comparative analysis of modern economic systems, which together reveal the content of the ecological paradigm of economic comparative studies of the XXI century. In our opinion, it is necessary 
to build the novel concept of economic comparative studies of the XXI century, based not only on traditional indicators-criteria (dominant forms of ownership of fixed assets and production results; ways to achieve macroeconomic equilibrium or plan-market ratio; features of income distribution and redistribution), but on such as: 1) dominant social values (economic, ecological, cultural, legal, etc.) and corresponding institutions; 2) the level of greening of the economic system; 3) the degree of environmental safety / danger; 4) the degree of sustainable development of the system; 5) public control over the system of relations "man - economy - ecology"; 6) share in the pollution of the planet; 7) participation in solving planetary environmental problems, etc.

In turn, these indicators-criteria for comparative analysis of modern economic systems can be specified in a number of environmental indicators-criteria, such as: 1) the share of environmental expenditures in GDP; 2) the degree of purity of air and water basins; 3) the magnitude of the radioactive background; 4) the degree of environmental friendliness of food; 5) the percentage of forest plantations to the total area; 6) the share of electricity produced by environmentally friendly technologies (using solar, wind, water); 7) the degree of utilization of environmentally harmful waste, etc.

\section{References}

1. Kulchytskyi Ya.V., Kulchytskyi B.V. (2015). Filosofiia ekonomichnykh system (rozvytok metodolohii yikh porivnialnoho analizu $\mathrm{v}$ umovakh ekolohizatsii, intelektualizatsii ta hlobalizatsii) [Philosophy of economic systems (development of methodology of their comparative analysis in the conditions of ecologization, intellectualization and globalization)]. Lviv: Liha-Pres, 710 p. [in Ukrainian]

2. Kulchytskyi Ya.V. (2011). Suchasni ekonomichni systemy v umovakh ekolohizatsii ta hlobalizatsii (teoretyko-metodolohichni zasady porivniannia) [Modern economic systems in the conditions of ecologization and globalization (theoretical and methodological principles of comparison)]. Lviv: Liha-Pres, 687 p. [in Ukrainian]

3. Kulchytskyi Ya.V. (2005). Problemy formuvannia sotsialno-ekolohichnykh suspilnykh vidnosyn $\mathrm{u}$ konteksti transformatsii suchasnykh ekoloho-ekonomichnykh system [Problems of formation of social and ecological social relations in the context of transformation of modern ecological and economic systems]. Lviv: Kamula, 144 p. [in Ukrainian]

4. Kulchytskyi Ya.V. (2003). Ekoloho-ekonomichni systemy (problemy teorii i metodolohii doslidzhennia) [Ecological and economic systems (problems of theory and research methodology)]. Lviv: UNFU, 64 p. [in Ukrainian]

5. Kulchytskyi Ya.V., Kulchytskyi B.V. (2007). Porivniannia ekonomichnykh system (problemy metodolohii) [Comparison of economic systems (problems of methodology)]. Lviv: Ivan Franko National University of Lviv, 318 p. [in Ukrainian]

6. Kulchytskyi Ya.V. (2008). Ekolohizatsiia ekonomichnykh system u konteksti postindustrialnoho paradyhmalnoho dyskursu ta ekonomichnoi komparatyvistyky [Ecologization of economic systems in the context of post-industrial paradigmatic discourse and economic comparative studies]. Regional Economy, № 1, pp. 77-84. [in Ukrainian]

7. Kulchytskyi Ya.V., Kulchytskyi B.V., Dzhyhora N.V. (2016). Instytutsiini zasady traktuvannia ekonomichnykh system $\mathrm{v}$ umovakh posylennia yikh ekolohizatsii ta hlobalizatsii [Institutional principles of interpretation of economic systems in terms of strengthening their greening and globalization], Bulletin of the National Forestry University of Ukraine: Economic Series, Iss. 26.6, pp. 7-13. [in Ukrainian]

8. Kulchytskyi Ya.V., Kulchytskyi B.V., Bashnianyn H.I., Osetskyi V.L. (2017). Filosofiia ekonomichnykh system u konteksti hnoseolohii suspilno-ekonomichnykh transformatsii [Philosophy of economic systems in the context of epistemology of socio-economic 
transformations] in Economic systems. Vol. 6, H.I.Bashnianyn (ed.). Lviv: Liha-Pres. [in Ukrainian]

9. Kulchytskyi Ya.V., Kulchytskyi B.V., Bashnianyn H.I., Osetskyi V.L. (2017). Instytutsiinyi pidkhid do traktuvannia ekonomichnykh system za umov posylennia yikh ekolohizatsii ta hlobalizatsii [Institutional approach to the interpretation of economic systems in terms of strengthening their greening and globalization], System analysis of economic systems. Proceedings of 2nd All-Ukrainian roundtable / H.I.Bashnianyn and B.M.Shevchyk (eds.). Lviv: Liha-Pres, pp. 9-15. [in Ukrainian]

10. Kulchytskyi Ya. (2017). Formuvannia ekolohichnoi svidomosti ta kultury pid chas vykladannia ekonomichnykh dystsyplin [Formation of ecological consciousness and culture during the teaching of economic disciplines], Ecologization of education as a factor of sustainable development of society: Materials of the International scientificpractical conference. Lviv: UNFU, pp. 68-71. [in Ukrainian]

11. Kulchytskyi Ya.V. (2018). Ekolohizatsiia ekonomichnykh system yak priorytet yikh transformatsii u XXI stolitti [Ecologization of economic systems as a priority of their transformation in the XXI century], Bulletin of the National Forestry University of Ukraine: Economic Series, vol. 28, № 4. [in Ukrainian]

12. Kulchytskyi Ya.V. (2018). Ekolohizatsiia ekonomichnykh system yak vyznachalna dominanta paradyhmalnykh zmin v ekonomichnii teorii XXI stolittia [Ecologization of economic systems as a defining dominant of paradigmatic changes in the economic theory of the XXI century], Bulletin of the National Forestry University of Ukraine: Economic Series, vol. 28, № 9. [in Ukrainian]

13. Kulchytskyi Ya.V. (2019). Ekolohichna paradyhma ekonomichnoi teorii XXI stolittia [Ecological paradigm of economic theory of the XXI century]. Anniversary collection of scientific works in honor of Professor Volodymyr Semenovych Kulchytsky on the occasion of the 100th anniversary of his birth, Lviv: Ivan Franko National University of Lviv, pp. 63-70. [in Ukrainian]

14. Kulchytskyi Ya., Kulchytskyi B., Moriak T., Ostroverkh P. (2019). Ekolohichni aspekty ekonomichnoi omparatyvistyky [Ecological aspects of economic comparative studies], Visnyk of Lviv University. Series Economics, Iss. 57. [in Ukrainian]

15. Melnyk V.P. (2010). Filosofiia. Nauka. Tekhnika: Metodoloho-svitohliadnyi analiz [Philosophy. Science. Technique: Methodological and worldview analysis], Lviv: Ivan Franko National University of Lviv, 592 p. [in Ukrainian]

16. Melnyk L.H. (2006). Osnovy stiikoho rozvytku [Fundamentals of sustainable development]. Sumy: University Book, 383 p. [in Ukrainian]

17. Tunytsia Yu. Yu. (2006). Ekoekonomika i rynok: podolannia superechnostei [Ecoeconomics and the market: overcoming contradictions], K.: Znannia, 314 p. [in Ukrainian]

18. Fiedor B., Czaja S., Graczyk A., Jakubczyk Z. (2012). Podstawy ekonomii środowiska i zasobów naturalnych [Fundamentals of Environment and Natural Resources Economics]. Fiedor B. (ed.), Warszawa: Wydawnictwo C.H. Beck, 484 p. [in Polish] 
B. Kulchytskyj, Ya. Kulchytskyj, P. Ostroverkh, T. Moryak

ISSN 2078-6115. Вісник Львівського університету. Серія економічна. 2020. Випуск 59

\title{
РОЗВИТОК МЕТОДОЛОГІЇ ПОРІВНЯЛЬНОГО АНАЛІЗУ ЕКОНОМІЧНИХ СИСТЕМ В УМОВАХ ПОСИЛЕННЯ ЇХ ЕКОЛОГІЗАЦІї
}

\author{
Б. Кульчицький ${ }^{1}$, Я. Кульчицький ${ }^{2}$, П. Островерх ${ }^{1}$, Т. Моряк ${ }^{1}$
}

\author{
${ }^{1}$ Львівський національний університет імені Івана Франка \\ 79008 м. Львів, проспект Свободи, 18 \\ E-mail: kulchytskyj.br@ukr.net \\ ${ }^{2}$ Начіональний лісотехнічний університет Украӥни \\ 79057 м. Львів, вул. Генерала Чупринки, 103
}

Анотація. Розкрито інституційні засади екологізації сучасних економічних систем 3 позицій постіндустріальної парадигми та економічної компаративістики в умовах посилення глобалізації. Виявлено зміст екологічної парадигми економічної теорії та обгрунтовано необхідність виокремлення соціально-екологічних відносин у системі економічних відносин суспільства. Проаналізовано концепцію стійкого розвитку та особливості еколого-економічних інструментів у розвинутих країнах.

Підкреслено важливість формування сучасної екологічної культури у процесі трансформації економічних систем, коли у піi основі мають бути орієнтованість на екологічну доцільність і безпеку, відсутність протиставлення людини і природи. Запропоновано авторське трактування процесу екологізації сучасних економічних систем в умовах посилення глобалізації, переходу людства до суспільства знань та "зеленої економіки". Під екологізацією економічних систем ми пропонуємо розуміти посилення екологічної спрямованості економічних систем у процесі їх трансформації, що виявляється у становленні сучасної економічної та екологічної свідомості і культури, екологічної відповідальності, утвердженні сучасних екологічних цінностей, формуванні відповідної нормативно-правової, інституційної бази, спрямованої на суспільний контроль за системою зв'язків "людина - економіка - екологія", застосуванні санкцій і стимулів щодо впливу економічної системи на стан екологічної рівноваги в умовах обмеженості природних ресурсів та загострення екологічної кризи глобального, регіонального і локального характеру. Екологізація економічних систем $\epsilon$ об'єктивним процесом їх трансформації, домінантою трансформації на зламі тисячоліть, що утверджує усвідомлення екологічних проблем як глобальних. Екологізація економічних систем розглядається сьогодні як дуже важливий, навіть визначальний критерій порівняльного аналізу національних систем чи наднаціональних системних утворень. Обгрунтовано екологічну парадигму економічної компаративістики XXI століття.

Ключові слова: економічні системи, екологізація економічних систем, стійкий розвиток, екологічна парадигма економічної теорії та економічної компаративістики XXI століття. 